\title{
The Potential of Microbial Fuel Cells for Remediation of Heavy Metals from Soil and Water-Review of Application
}

\author{
Chaolin Fang ${ }^{1}$ and Varenyam Achal ${ }^{1,2, *}$ \\ 1 Environmental Engineering Program, Guangdong Technion-Israel Institute of Technology, \\ Shantou 515063, China; chaolin.fang@gtiit.edu.cn \\ 2 Technion-Israel Institute of Technology, Haifa 3200, Israel \\ * Correspondence: varenyam.achal@gtiit.edu.cn or varenyam@technion.ac.il
}

Received: 17 October 2019; Accepted: 11 December 2019; Published: 13 December 2019

\begin{abstract}
The global energy crisis and heavy metal pollution are the common problems of the world. It is noted that the microbial fuel cell (MFC) has been developed as a promising technique for sustainable energy production and simultaneously coupled with the remediation of heavy metals from water and soil. This paper reviewed the performances of MFCs for heavy metal removal from soil and water. Electrochemical and microbial biocatalytic reactions synergistically resulted in power generation and the high removal efficiencies of several heavy metals in wastewater, such as copper, hexavalent chromium, mercury, silver, thallium. The coupling system of MFCs and microbial electrolysis cells (MECs) successfully reduced cadmium and lead without external energy input. Moreover, the effects of $\mathrm{pH}$ and electrode materials on the MFCs in water were discussed. In addition, the remediation of heavy metal-contaminated soil by MFCs were summarized, noting that plant-MFC performed very well in the heavy metal removal.
\end{abstract}

Keywords: microbial fuel cell; microbial electrolysis cell; heavy metals; wastewater

\section{Introduction}

Fossil fuels are the most widely used but exhaustible energy sources and it is estimated that oil, gas, coal, or uranium will be depleted in 55-75 years [1]. On the other hand, the continued use of fossil fuels has brought a series of environmental issues, such as enormous carbon dioxide emission and thermal pollution. In the context of the global energy crisis and environmental issues, researchers are exploring solar, wind, tidal, geothermal, biomass energy, and other biofuels as alternative renewable energy sources. Such resources are increasing dramatically in recent years. Notably, microbial fuel cells (MFCs) are considered as an alternative strategy because of their excellent abilities to produce electricity and remove pollutants simultaneously. Dating back to 1911, the potential of microbes in generating electricity was revealed by Potter's work that a voltage of $0.3-0.5 \mathrm{~V}$ was obtained when a platinum electrode was inserted into a liquid suspension of yeast and Escherichia coli using a glucose medium [2]. This discovery was the advent of MFCs research. Nevertheless, early attention to MFCs was in the 1950s as research communities were looking for a new technique, which could convert human waste to electricity timely during space flights [3]. Until the 1980s, redox-active mediators were widely used in MFCs, and it significantly improved the power density output of MFCs. At this point, the feasibility of MFCs as small power supplies increased and more researchers got interested in the research and development of MFCs in regard to alternative renewable energy systems.

In simpler words, MFCs are devices that use exoelectrogenic microorganisms as biocatalysts and then convert chemical energy to electrical energy directly via substrate oxidation $[4,5]$. A typical 
electrode reaction using acetate as a substrate [6] and a two-chamber MFC setup (Figure 1) are shown below:

$$
\begin{gathered}
\text { Anodic reaction : } \mathrm{CH}_{3} \mathrm{COO}^{-}+2 \mathrm{H}_{2} \mathrm{O} \stackrel{\text { microbes }}{\rightarrow} 2 \mathrm{CO}_{2}+7 \mathrm{H}^{+}+8 \mathrm{e}^{-} \\
\text {Cathodic reaction : } \mathrm{O}_{2}+4 \mathrm{e}^{-}+4 \mathrm{H}^{+} \rightarrow 2 \mathrm{H}_{2} \mathrm{O} .
\end{gathered}
$$

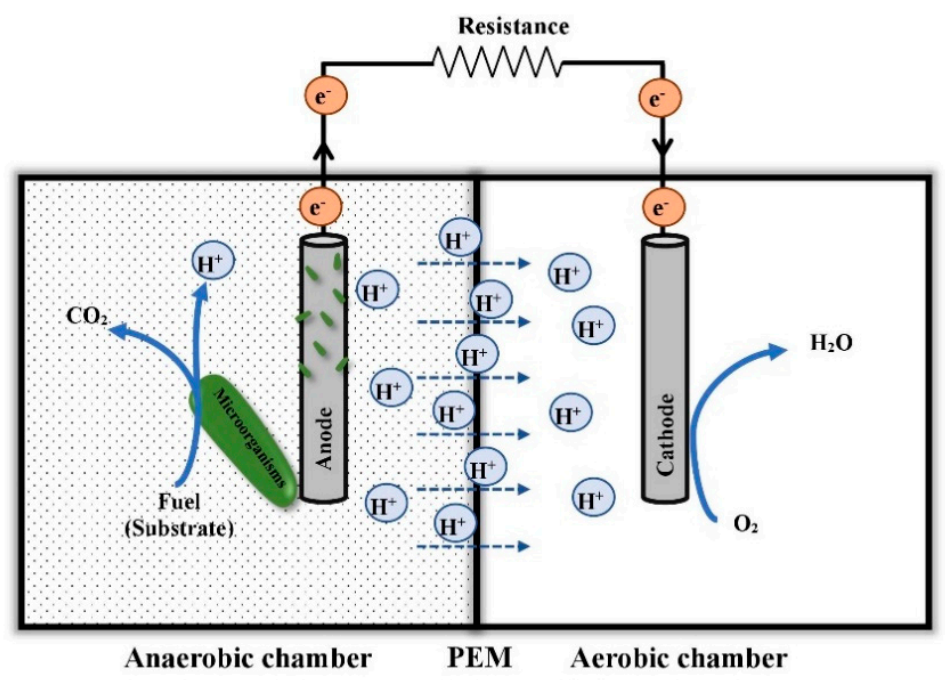

Figure 1. Schematic of a typical two-chamber microbial fuel cell.

In MFCs, microorganisms oxidize organic substrates in the anode chamber under anaerobic condition, resulting in the production of protons and release of electrons, and electrons flow from the anode to the cathode through an external circuit. These electrons combine with protons and an electron acceptor (mainly oxygen) on the cathode surface to produce water. Plus, the anode chamber and the cathode chamber get separated by a proton exchange membrane (PEM) that allows protons to transfer from anode to cathode and prevents oxygen diffusion to the anode chamber [7]. The developments and advancements of MFCs have been made to improve electricity generation over the years, for instance, enhancing bacterial electron transfer toward the MFCs anode [8,9], optimizing electrode materials [10,11], and developing different MFCs configurations [12,13].

More remarkably, MFCs systems have been used to accomplish wastewater treatment/bioremediation along with power generation [14-17]. Exoelectrogenic microorganisms in MFCs could utilize nearly any source of biodegradable organic or inorganic matter that does not directly require oxygen as a part of the degradation process in wastewater for electrical power generation [18]. When MFCs are implemented in wastewater treatment, there are some obvious advantages, including: (i) serving as energy neutral wastewater treatment, while conventional aerobic treatments consume large amounts of electrical energy for aeration [19,20]; (ii) generating less excess activated sludge compared to anaerobic digesters [21]. It is worth noting that the attention for the application of MFCs regarding the biological reduction of heavy metals from wastewater and soil has increased in recent years.

Although it is well known that heavy metals are natural components of the ecosystem [22], they are also the most dangerous species among environmental pollutants [23]. Copper $(\mathrm{Cu})$, chromium $(\mathrm{Cr})$, cadmium $(\mathrm{Cd})$, lead $(\mathrm{Pb})$, and mercury $(\mathrm{Hg})$, among other heavy metals ions, would accumulate in the body through the food chain rather than degrade into the harmless products [24] and may induce many adverse effects on living organisms due to their high toxicity and carcinogenicity even at trace levels $[25,26]$. Currently the large amount of heavy metals in water and soil are released from anthropogenic sources, such as mining, metallurgy, electroplating, electrolysis, batteries, tanneries, pesticide, and fertilizer. The World Health Organization (WHO) set the guideline value of heavy metals for drinking water, for instance, $2 \mathrm{mg} / \mathrm{L} \mathrm{Cu}, 0.05 \mathrm{mg} / \mathrm{L} \mathrm{Cr}, 0.003 \mathrm{mg} / \mathrm{L} \mathrm{Cd}, 0.01 \mathrm{mg} / \mathrm{L} \mathrm{Pb}, 0.006 \mathrm{mg} / \mathrm{L} \mathrm{Hg}$, and $0.01 \mathrm{mg} / \mathrm{L} \mathrm{As} \mathrm{[27].} \mathrm{However,} \mathrm{the} \mathrm{maximum} \mathrm{contaminant} \mathrm{levels} \mathrm{for} \mathrm{these} \mathrm{heavy} \mathrm{metal} \mathrm{are} \mathrm{often} \mathrm{far}$ 
exceeded in many water sources because of various wastewater sources [28]. According to the official data, although the overall level of heavy metal emissions in China tended to decrease over the past ten years, the emission of heavy metals from wastewater remains huge. In 2017 alone, high amounts of metals were released including Pb of $38,342.2 \mathrm{~kg}$, Cd of $7126.9 \mathrm{~kg}$, As of $34,317.0 \mathrm{~kg}, \mathrm{Cr}$ (IV) of $27,711.5 \mathrm{~kg}$, and $\mathrm{Hg}$ of $880.2 \mathrm{~kg}$ [29]. At the same time, heavy metal-contaminated soil also has been reported in China and many other countries [30-32].

At present, heavy metal pollutions are regarded as the most serious environmental problems and heavy metal removal from wastewater and soil has been extensively investigated and studied. MFCs could attract so much attention from worldwide researchers as they are satisfactorily functioning on the remediation of heavy metal pollution in water and soil together with power generation. In this work, the objectives were to review the application of MFCs on the biological reduction of heavy metals from wastewater and soil. Meanwhile, some factors that affect the MFCs' performances were discussed to provide more information for future studies. Furthermore, the outlooks were raised at the end of this paper.

\section{Effect of Factors on Heavy Metal Reduction from Wastewater in MFCs}

\subsection{Effects of $p H$}

The presence of PEM is a transport barrier for the protons to cross membrane diffusion. At the earlier stage of MFC, the production rate of protons in the anode exceeds its consumption rate in the cathode chambers. Thus, there is a $\mathrm{pH}$ shift and finally it does reach a dynamic equilibrium [6]. The $\mathrm{pH}$ of the electrolyte is crucial to the MFCs' stability and the bioelectrochemical performance and metal recovery of MFCs in wastewater. Generally, a neutral $\mathrm{pH}$ condition in the anodic chamber is preferable for the growth of exoelectrogenic microorganisms [33], while many metals' reduction reactions in the cathodic chamber are strongly dependent on low $\mathrm{pH}[34,35]$.

One typical $\mathrm{Cr}(\mathrm{VI})$ reduction in MFC is presented in Equation (3) and the low $\mathrm{pH}$ could positively affect the metal's recovery. Higher $\mathrm{H}^{+}$serving as enough reactant participated in the reduction reaction [36]. According to Nernst's equation (Equation (4)) and the definition of cell potential ( $\left.\mathrm{E}_{\text {cell }}\right)$ (Equation (5)), $\mathrm{E}_{\text {cell }}$ would be increased by increasing $\mathrm{H}^{+}$and initial $\mathrm{Cr}^{6+}$ concentration. Furthermore, the maximum power density increment might be due to a decrease in internal resistance resulting from the increase of ionic strength [37]. In the literature, the internal resistance was $300 \Omega$ at $50 \mathrm{ppm}$ $\mathrm{Cr}^{6+}$ and then decreased to $100 \Omega$ at $500 \mathrm{ppm} \mathrm{Cr}^{6+}$ [38].

$$
\begin{gathered}
\mathrm{Cr}_{2} \mathrm{O}_{7}^{2-}+14 \mathrm{H}^{+}+6 \mathrm{e}^{-} \rightarrow 2 \mathrm{Cr}^{3+}+7 \mathrm{H}_{2} \mathrm{O}\left(\mathrm{E}^{0}=1.33 \mathrm{~V}\right) \\
\mathrm{E}_{\text {cat }}=\mathrm{E}_{\text {cat }}^{0}-\frac{\mathrm{RT}}{\mathrm{nF}} \ln \frac{\left[\mathrm{Cr}^{3+}\right]^{2}}{\left[\mathrm{Cr}_{2} \mathrm{O}_{7}^{2-}\right]\left[\mathrm{H}^{+}\right]^{14}} \\
\mathrm{E}_{\text {cell }}=\mathrm{E}_{\text {cat }}-\mathrm{E}_{\mathrm{an}}
\end{gathered}
$$

where $\mathrm{E}_{\text {cat }}^{0}$ is the standard cathode potential $\left(1.33 \mathrm{~V}\right.$ vs. Standard Hydrogen Electrode, SHE; $\mathrm{H}^{+}=1$ $\mathrm{M}, \mathrm{pH}=0)$; The thermodynamic anode potential $\left(\mathrm{E}_{\mathrm{an}}\right)$ at $\mathrm{pH} 7$ and $298.15 \mathrm{~K}$ is a constant; $\mathrm{R}$ is the ideal gas constant $(8.314 \mathrm{~J} / \mathrm{mol} \mathrm{K})$; $\mathrm{T}$ is the temperature $(\mathrm{K}) ; \mathrm{n}$ is the number of electrons exchanged; $\mathrm{F}$ is the Faraday's constant $(96,485 \mathrm{C} / \mathrm{mol}) ;\left[\mathrm{H}^{+}\right],\left[\mathrm{Cr}^{3+}\right]$, and $\left[\mathrm{Cr}_{2} \mathrm{O}_{7}{ }^{2-}\right]$ are the concentrations of the three types of ions in solution.

$\mathrm{Cu}^{2+}$ may precipitate as $\mathrm{CuO}, \mathrm{Cu}_{2} \mathrm{O}$, or other forms not available for reduction at $\mathrm{pH} 4.5$ or higher and low $\mathrm{pH}$ is necessary for the copper reduction in a cathode chamber [39]. During the cathodic reduction of $\mathrm{Cu}^{2+}$ in MFC, two products of $\mathrm{Cu}$ or $\mathrm{Cu}_{2} \mathrm{O}$ could be formed on the cathode in MFC (Equations (6) and (7)). $\mathrm{H}^{+}$has no effect of on $\mathrm{Cu}^{2+}$ reduction to pure $\mathrm{Cu}$ based on Equation (6). However, under a low-pH environment, the increase of $\mathrm{H}^{+}$concentration leads to the increase of $\mathrm{E}_{\text {cat }}\left(\mathrm{Cu}_{2} \mathrm{O} / \mathrm{Cu}\right)$ and the decrease of $\mathrm{E}_{\mathrm{cat}}\left(\mathrm{Cu}^{2+} / \mathrm{Cu}_{2} \mathrm{O}\right)$ demonstrated in the following Nernst equation 
(Equations (9) and (10)) [40]. As a result, $\mathrm{Cu}^{2+}$ to $\mathrm{Cu}$ would be more favorable than $\mathrm{Cu}^{2+}$ to $\mathrm{Cu}_{2} \mathrm{O}$ and more $\mathrm{Cu}_{2} \mathrm{O}$ could be further reduced to $\mathrm{Cu}$ (Equation (8)).

$$
\begin{gathered}
\mathrm{Cu}^{2+}+2 \mathrm{e}^{-} \rightarrow \mathrm{Cu}\left(\mathrm{E}^{0}=0.337 \mathrm{~V}\right) \\
2 \mathrm{Cu}^{2+}+\mathrm{H}_{2} \mathrm{O}+2 \mathrm{e}^{-} \rightarrow \mathrm{Cu}_{2} \mathrm{O}+2 \mathrm{H}^{+}\left(\mathrm{E}^{0}=0.207 \mathrm{~V}\right) \\
\mathrm{Cu}_{2} \mathrm{O}+2 \mathrm{e}^{-}+2 \mathrm{H}^{+} \rightarrow 2 \mathrm{Cu}+\mathrm{H}_{2} \mathrm{O}\left(\mathrm{E}^{0}=0.059 \mathrm{~V}\right) \\
\mathrm{E}_{\mathrm{cat}}\left(\mathrm{Cu}^{2+} / \mathrm{Cu}_{2} \mathrm{O}\right)=\mathrm{E}_{\mathrm{cat}}^{0}\left(\mathrm{Cu}^{2+} / \mathrm{Cu}_{2} \mathrm{O}\right)-\frac{\mathrm{RT}}{\mathrm{nF}} \ln \frac{\left[\mathrm{H}^{+}\right]^{2}}{\left[\mathrm{Cu}^{2+}\right]^{2}} \\
\mathrm{E}_{\mathrm{cat}}\left(\mathrm{Cu}_{2} \mathrm{O} / \mathrm{Cu}\right)=\mathrm{E}_{\mathrm{cat}}^{0}\left(\mathrm{Cu}_{2} \mathrm{O} / \mathrm{Cu}\right)-\frac{\mathrm{RT}}{\mathrm{nF}} \ln \frac{1}{\left[\mathrm{H}^{+}\right]^{2}}
\end{gathered}
$$

In another study, the maximum $\mathrm{Hg}^{2+}$ removal was realized at $\mathrm{pH} 2$ together with the maximum power generation of $318.7 \mathrm{~mW} / \mathrm{m}^{2}$ higher than $4.21 \pm 0.34,4.84 \pm 0.00$, and $5.25 \pm 0.36 \mathrm{mg} / \mathrm{L}$ for an initial $\mathrm{pH}$ of 3,4 , and 4.8 , respectively. $\mathrm{H}^{+}$concentration also has no effect of the reduction of $\mathrm{Hg}^{2+}$ and its reduced product of $\mathrm{Hg}_{2}{ }^{2+}$ according to reduction equations (Equations (11)-(13)), but $\mathrm{H}^{+}$ enhanced the removal of $\mathrm{Hg}^{2+}$ by chemical mechanism [41]. $\mathrm{Hg}_{2}{ }^{2+}$ was precipitated in the presence of $\mathrm{Cl}^{-}$(Equation (14)) and $\mathrm{Hg}_{2} \mathrm{Cl}_{2}$ dissolved at low $\mathrm{pH}$ to generate higher $\mathrm{Hg}^{2+}$. Subsequently, $\mathrm{Hg}_{2}{ }^{2+}$ was further reduced to $\mathrm{Hg}(0)$ and the mercury concentration decreased in effluent (Equation (15)). In addition, the maximum power density increased from 8.9 to $318.7 \mathrm{~mW} / \mathrm{m}^{2}$ with a decrease in $\mathrm{pH}$ value from 4.8 to 2 . $\mathrm{H}^{+}$does not determine the standard potential of $\mathrm{Hg}^{2+}$ or $\mathrm{Hg}_{2}{ }^{2+}$, according to the Nernst equation. Herein, the effect of $\mathrm{pH}$ on the maximum power densities should be due to the decreased internal resistance caused by the increase of ionic strength.

$$
\begin{gathered}
2 \mathrm{Hg}^{2+}+2 \mathrm{e}^{-} \rightarrow \mathrm{Hg}_{2}^{2+}\left(\mathrm{E}^{0}=0.911 \mathrm{~V}\right) \\
\mathrm{Hg}_{2}^{2+}+2 \mathrm{e}^{-} \rightarrow 2 \mathrm{Hg}\left(\mathrm{E}^{0}=0.796 \mathrm{~V}\right) \\
\mathrm{H}^{2+}+2 \mathrm{e}^{-} \rightarrow \mathrm{Hg}\left(\mathrm{E}^{0}=0.851 \mathrm{~V}\right) \\
\mathrm{Hg}_{2}^{2+}+2 \mathrm{Cl}^{-} \rightarrow \mathrm{Hg}_{2} \mathrm{Cl}_{2} \\
\mathrm{Hg}_{2} \mathrm{Cl}_{2}+2 \mathrm{e}^{-} \rightarrow 2 \mathrm{Hg}+2 \mathrm{Cl}^{-}\left(\mathrm{E}^{0}=0.268 \mathrm{~V}\right)
\end{gathered}
$$

\subsection{Effects of Cathode Materials}

Clearly, the cathode material is a very important factor for the MFC system, and it affects the performance of MFCs. Typically, a good cathode material should have the following properties: excellent electrical conductivity, large surface area, good stability, and economic. The commonly used carbon-based cathode materials contain graphite (e.g., graphite foil, graphite plate, graphite felt, graphite rod, etc.) and plain carbon (e.g., carbon cloth, carbon paper, carbon brush, carbon felt, carbon fiber, carbon rod, etc.). Metal-based cathodic materials, such as stainless steel mesh, nickel foam, titanium sheet, also have been used as cathode electrodes in MFCs $[42,43]$ and they have advantages of higher electrical conductivity, avid facilitation of microbial adhesion, and durability [5]. But obviously, these metal-based cathodic materials are not cheap and increase the cost of the MFCs.

Activation losses, ohmic losses, and mass transport losses in voltage reduce the real voltage output $\left(\mathrm{V}_{\mathrm{op}}\right)$ and affect MFC performance. When the thermodynamically predicted voltage of an MFC subtracts the voltage losses of each compartment, $\mathrm{V}_{\mathrm{op}}$ can be determined as follows [44]:

$$
\mathrm{V}_{\mathrm{op}}=\mathrm{E}_{\text {cell }}-\left[\left(\eta_{\text {act }}+\eta_{\text {ohmic }}+\eta_{\text {conc }}\right)_{\text {cat }}+\left(\eta_{\text {act }}+\eta_{\text {ohmic }}+\eta_{\text {conc }}\right)_{\text {an }}\right]
$$


where $E_{\text {cell }}$ is the thermodynamic cell voltage, $\eta_{\text {act }}$ is the activation loss due to reaction kinetics, $\eta_{\text {ohmic }}$ is the ohmic loss from ionic and electronic resistances, and $\eta_{\text {conc }}$ is the concentration loss due to mass transport limitations.

The cathode internal resistance is an important limiting factor for the power output of MFCs, which is further divided into charge transfer resistance of the electrodes, ohmic resistance, and diffusion resistance [45]. Electrochemical impedance spectroscopy (EIS) can be used to determine the individual components of the internal resistance. The cathodic ohmic includes the resistance from the electrode, member, electrolytes, and interconnections in the cathode and it plays a very minor role in comparison with charge transfer resistance [46]. Moreover, the cathodic ohmic could be reduced by changing the cell design and shortening the electrode distance [47]. Liu et al. [37] reported that the a decrease of the distance between the anode and cathode that was from 4 to $2 \mathrm{~cm}$ resulted in an increase of the power density from 720 to $1210 \mathrm{~mW} / \mathrm{m}^{2}$. The charge transfer resistance is related to the activation energy of the cathode. A smaller charge transfer resistance of the cathode indicates a higher kinetic driving force and a lower hindrance to charge transport [48]. Sometimes, cathode materials are coated with catalysts (e.g., $\mathrm{Pt}, \mathrm{MnO}_{2}$ ) to increase the kinetics of oxygen reduction at the electrode surface and reduce the cathodic reaction activation energy [44,49]. In a $\mathrm{Cr}(\mathrm{VI})$ reduction experiment via MFC system using carbon cloth, carbon brush, and carbon felt as cathode materials [50], the ohmic resistance of three electrode materials were 5.6, 4.8, and $4.3 \Omega$, respectively and the charge transfer resistance of three electrode materials were 7.52, 73.86, and $113.66 \Omega$, respectively. In terms of $\mathrm{Cr}(\mathrm{VI})$ removal efficiency, results showed a higher rate constant value of 0.1567 per hour $\left(0.1567 \mathrm{~h}^{-1}\right)$ in MFC with carbon cloth cathode than that of carbon brush cathode $\left(0.1064 \mathrm{~h}^{-1}\right)$ and carbon felt cathode $\left(0.0719 \mathrm{~h}^{-1}\right)$. Three MFC systems achieved the complete $\mathrm{Cr}(\mathrm{VI})$ removal in 72, 300, and $444 \mathrm{~h}$, respectively. At the same time, the maximum power density MFC with carbon cloth electrode was $1221.91 \mathrm{~mW} / \mathrm{m}^{2}$ and it was 2.69 folds and 8.49 folds higher than that of carbon brush electrode and carbon felt electrode, respectively.

\section{MFCs Performances on Heavy Metal Removal in Wastewater}

To date, various physical, chemical, and biological technologies have been developed for the removal of heavy metals from wastewater and soil, such as chemical precipitation, ion exchange, membrane filtration, biosorption, bioremediation, etc. [25,28,51]. However, there are some technical or economic constraints that always restrict the application of these techniques, including high energy input, excessive chemicals consumption, and substantial toxic waste sludge $[35,52,53]$. On the other hand, MFCs are cost-effective and environmentally friendly technologies, and they can reduce heavy metals from wastewater and soil with high removal efficiency and electricity generation [54].

MFCs are constructed to remove heavy metals through the cathodic reduction reaction, while organic substrates are oxidized and serve as the carbon and electron donor at the anode [34]. In addition, previous studies found that biosorption and precipitation reactions (sulfides, hydroxides) also made significant contributions on the removal of heavy metals in MFC systems [55-57]. A summary of some applications of MFCs on heavy metal removal in wastewater is presented in Table 1 and the part of metal reductions is described in detail.

\subsection{Copper Removal}

A membrane-less single-chamber MFC was constructed for the copper removal. Such an MFC system can help reduce the MFCs cost from the membrane for the long-term wastewater treatment [58]. Results showed that copper was removed efficiently with a removal efficiency of $98.3 \%$ in $28 \mathrm{~h}$ at the tolerable $\mathrm{Cu}^{2+}$ concentration of $12.5 \mathrm{mg} / \mathrm{L}$ and the product of $\mathrm{CuO}$ and $\mathrm{Cu}_{2} \mathrm{O}$ was deposited on the biocathode. The maximum power density was $10.2 \mathrm{~W} / \mathrm{m}^{3}$. The main functional exoelectrogen and tolerant copper microorganisms were from the phylum Proteobacteria and the genus of Acinetobacter and Geobacter with Geobacter metallireducens and Geobacter sulfurreducens as prime species. Meanwhile, it was observed that $\mathrm{Cu}^{2+}$ concentration was negatively associated with voltage and maximum power density that could be due to higher $\mathrm{Cu}^{2+}$ concentration inhibiting the activity of microorganisms. 
A bipolar membrane was applied to maintain the $\mathrm{pH}$ difference between the anode and cathode chambers [59]. Under anaerobic and aerobic conditions, the metallurgical MFC demonstrated excellent performances on copper reduction in copper-containing waste streams, indicating that the maximum copper removal efficiency was calculated to be $99.88 \%$ and $99.95 \%$ in seven days, respectively. MFC system also improved the maximum power density of 0.43 to $0.80 \mathrm{~W} / \mathrm{m}^{2}$. In this process, scanning electron microscopy and $\mathrm{X}$-ray powder diffraction confirmed that the product of copper removal was pure copper crystals, not $\mathrm{CuO}$ or $\mathrm{Cu}_{2} \mathrm{O}$ [39].

\subsection{Hexavalent Chromium Removal}

In general, hexavalent chromium $\mathrm{Cr}(\mathrm{VI})$ and trivalent chromium $\mathrm{Cr}(\mathrm{III})$ are main valence states of chromium in the natural environment. $\mathrm{Cr}(\mathrm{VI})$ is water soluble with high toxicity in the full $\mathrm{pH}$ range, while $\mathrm{Cr}(\mathrm{III})$, being less mobile, is less toxic and tends to form $\mathrm{Cr}(\mathrm{OH})_{3}$ precipitates. The reduction of $\mathrm{Cr}(\mathrm{VI})$ to $\mathrm{Cr}(\mathrm{III})$ is a common remediation pathway of wastewater containing $\mathrm{Cr}(\mathrm{VI})$ [34]. Li et al. [50] operated a two-chamber MFC to reduce $\mathrm{Cr}(\mathrm{VI})$ to non-toxic $\mathrm{Cr}(\mathrm{III})$ using three different cathode materials- the carbon cloth, carbon brush, and carbon felt. Results showed that $80 \mathrm{mg} / \mathrm{L} \mathrm{Cr}(\mathrm{VI})$ was completely removed by MFC with carbon cloth cathode in $72 \mathrm{~h}$ at an optimized $\mathrm{pH}$ of 2 while only $33.45 \%$ and $12.72 \%$ of $\mathrm{Cr}(\mathrm{VI})$ removal efficiency were obtained using carbon brush and carbon felt as cathode materials, respectively. The MFC maximum power density with carbon cloth electrode was $1221.91 \mathrm{~mW} / \mathrm{m}^{2}$, which was 2.69 folds and 8.49 folds higher than that of carbon brush electrode and carbon felt electrode, respectively.

It is a common case that one practical wastewater contains multiple metals, for example, $\mathrm{Cr}(\mathrm{VI})$ and vanadium $\mathrm{V}(\mathrm{V})$ are common pollutants in vanadium-containing wastewater. Herein, when MFC was applied for the remediation of such wastewater, $\mathrm{V}(\mathrm{V})$ and $\mathrm{Cr}(\mathrm{VI})$ acted as two different electron acceptors in double-chamber MFC [60]. As a result, the $\mathrm{V}(\mathrm{V})$ and $\mathrm{Cr}(\mathrm{VI})$ reduction efficiencies were $67.9 \% \pm 3.1 \%$ and $75.4 \% \pm 1.9 \%$ in $240 \mathrm{~h}$, respectively, with a maximum power density of $970.2 \pm 20.6 \mathrm{~mW} / \mathrm{m}^{2}$. The product of $\mathrm{Cr}(\mathrm{VI})$ reduction mainly was $\mathrm{Cr}(\mathrm{III})$ in the form of hydroxide deposited on the cathode and vanadium was precipitated or soluble depending on the $\mathrm{pH}$ of exhausted catholyte.

\subsection{Cadmium (Cd) Removal}

The standard redox potential of the $\mathrm{Cd}(\mathrm{II}) / \mathrm{Cd}(0)$ is $-0.40 \mathrm{~V}$ and it is difficult to make its reduction into elemental metal by a single MFC because MFCs cannot generate a sufficient voltage and power. Microbial electrolysis cells (MECs) are regarded as potential bio-electrochemical technologies to reduce heavy metals with external power supply request and have been used to reduce Cd (II) [61]. Choi et al. [62] studied that Cd (II)-MEC coupled with Cr(VI)-MFC to recover Cd (II) without external energy input. Consequently, $\mathrm{Cr}(\mathrm{VI})-\mathrm{MFC}$ could successfully complement the insufficient voltage and power needed during the $\mathrm{Cd}(\mathrm{II})$ reduction in $\mathrm{Cd}(\mathrm{II})-\mathrm{MEC}$ system. After $60 \mathrm{~h}$ reaction, the removal efficiencies of $200 \mathrm{ppm} \mathrm{Cr}(\mathrm{VI})$ and $50 \mathrm{ppm} \mathrm{Cd}(\mathrm{II})$ were $13.95 \% \pm 0.73 \%$ and $93.43 \% \pm 0.17 \%$, respectively. The maximum output power $\left(22.5 \mathrm{Wm}^{2}\right)$ of $\mathrm{Cr}(\mathrm{VI})-\mathrm{MFC}$ was 11.3 times higher than the highest power density supplied to $\mathrm{Cd}(\mathrm{II})-\mathrm{MFC}\left(2.0 \mathrm{Wm}^{2}\right)$. Plus $\mathrm{Pb}$ (II)-MEC connected with $\mathrm{Cr}$ (VI)-MFC were also designed to simultaneously reduce $\mathrm{Cr}(\mathrm{VI})$ and $\mathrm{Pb}(\mathrm{II})$ successfully without external energy input [42].

The effects of $\mathrm{Cd}$ on the power generation of a single-chamber air-cathode MFC and Cd removal in MFC were investigated by Abourached et al. [55]. Firstly, the Cd maximum tolerable concentration of the electrochemically active microorganisms was $200 \mathrm{mM}$ in MFC. The decreased rate of MFC voltage output caused by the gradual increase of $C d$ concentrations with an $100 \mathrm{mM}$ increment was slower than that of MFCs, which were fed with $300 \mathrm{mM} \mathrm{Cd}$ medium solution directly. Notably, the high power generation of $3.6 \mathrm{~W} / \mathrm{m}^{2}$ was achieved simultaneously with a high Cd removal efficiency of $90 \%$. However, the probable product of Cd removal was CdS and the high removal efficiency of Cdwas realized mainly through biosorption and sulfide precipitation rather than through cathodic reduction. 
Table 1. Microbial fuel cells (MFCs) for the removal of heavy metals from wastewater.

\begin{tabular}{|c|c|c|c|c|}
\hline Metal & MFC Fabrication & $\begin{array}{c}\text { Maximum Removal } \\
\text { Efficiency }\end{array}$ & $\begin{array}{c}\text { Maximum Power } \\
\text { Generation }\end{array}$ & References \\
\hline $\mathrm{Cu}(\mathrm{II})$ & $\begin{array}{c}\text { Single-chamber MFC, } \\
\text { Carbon brush for anode, } \\
\text { Carbon cloth/Pt coated for cathode }\end{array}$ & $98.3 \%$ & $10.2 \mathrm{~W} / \mathrm{m}^{3}$ & {$[40,58]$} \\
\hline $\mathrm{Cu}(\mathrm{II})$ & $\begin{array}{l}\text { Two-chamber MFC, } \\
\text { Graphite plate for anode, } \\
\text { Graphite foil for cathode }\end{array}$ & $\begin{array}{c}\text { 99.88\% (Anaerobic) } \\
\text { 99.95\% (Aerobic) }\end{array}$ & $\begin{array}{c}0.43 \mathrm{~W} / \mathrm{m}^{2} \text { (Anaerobic) } \\
0.80 \mathrm{~W} / \mathrm{m}^{2} \text { (Aerobic) }\end{array}$ & [39] \\
\hline $\mathrm{Cr}(\mathrm{VI})$ & $\begin{array}{c}\text { Two-chamber MFC, } \\
\text { Carbon felt for anode, } \\
\text { Carbon cloth }{ }^{(\mathrm{a})} / \text { Carbon brush }^{(\mathrm{b})} / \\
\text { Carbon felt }^{(\mathrm{c})} \text { for cathode }\end{array}$ & $\begin{array}{c}100 \%{ }^{(a)} \\
33.45 \%^{(b)} \\
12.72 \%{ }^{(c)}\end{array}$ & $1221.91 \mathrm{~mW} / \mathrm{m}^{2}$ & {$[50]$} \\
\hline $\begin{array}{l}\mathrm{Cr}(\mathrm{VI}) \text { and } \\
\quad \mathrm{V}(\mathrm{V})\end{array}$ & $\begin{array}{c}\text { Two-chamber MFC, } \\
\text { Carbon fiber felt for anode; } \\
\text { Carbon fiber felt for cathode }\end{array}$ & $\begin{array}{c}75.4 \% \pm 1.9 \% \mathrm{Cr}(\mathrm{VI}) \\
67.9 \% \pm 3.1 \% \mathrm{~V}(\mathrm{~V})\end{array}$ & $970.2 \pm 20.6 \mathrm{~mW} / \mathrm{m}^{2}$ & {$[60]$} \\
\hline $\mathrm{Cd}(\mathrm{II})$ & $\begin{array}{c}\text { Single-chamber MFC; } \\
\text { Carbon cloth for anode; } \\
\text { Carbon cloth/Pt coated for cathode }\end{array}$ & $90 \%$ & $3.6 \mathrm{~W} / \mathrm{m}^{2}$ & [55] \\
\hline $\begin{array}{l}\mathrm{Cr}(\mathrm{VI}) \text { and } \\
\quad \mathrm{Cd}(\mathrm{II})\end{array}$ & $\begin{array}{l}\text { Two double-chambers MFC-MEC } \\
\text { (microbial electrolysis cell), } \\
\text { carbon brush and carbon cloth for anode } \\
\text { and cathode } \\
\text { of both } \mathrm{Cr}(\mathrm{VI})-\mathrm{MFC} \text { and Cd(II)-MEC }\end{array}$ & $\begin{array}{c}13.95 \% \pm 0.73 \% \\
\text { (for } 200 \mathrm{ppm} \mathrm{Cr}(\mathrm{VI}) \text { ) } \\
93.43 \% \pm 0.17 \% \\
\text { (for } 50 \mathrm{ppm} \text { for } \mathrm{Cd}(\mathrm{II}) \text { ) }\end{array}$ & $22.5 \mathrm{~W} / \mathrm{m}^{2}$ & [62] \\
\hline $\mathrm{Hg}(\mathrm{II})$ & $\begin{array}{l}\text { Two-chamber MFC, } \\
\text { Graphite felt for anode, } \\
\text { Carbon paper for cathode }\end{array}$ & $\begin{array}{c}\text { i. } 3.08 \pm 0.07 \mathrm{mg} / \mathrm{L} \\
(\mathrm{pH}=2) \\
\text { ii. } 99.54 \% \\
\text { (for } 100 \mathrm{mg} / \mathrm{L} \mathrm{Hg}(\mathrm{II}))\end{array}$ & $\begin{array}{c}\text { i. } 318.7 \mathrm{~mW} / \mathrm{m}^{2} \\
\quad(\mathrm{pH}=2) \\
\text { ii. } 433.1 \mathrm{~mW} / \mathrm{m}^{2} \\
\text { (For } 100 \mathrm{mg} / \mathrm{L} \mathrm{Hg}(\mathrm{II}))\end{array}$ & [41] \\
\hline $\operatorname{Ag}(\mathrm{I})$ & $\begin{array}{l}\text { Two-chamber MFC, } \\
\text { Carbon brush for anode, } \\
\text { Carbon cloth for cathode }\end{array}$ & $\begin{array}{c}99.91 \% \pm 0.00 \% \\
\text { (for } 50 \text { ppm } \operatorname{Ag}(\mathrm{I}) \text { ) }\end{array}$ & $\begin{array}{c}4.25 \mathrm{~W} / \mathrm{m}^{2} \\
\left(\text { For } \mathrm{Ag}^{+} \mathrm{ppm}, \mathrm{pH}=7\right)\end{array}$ & {$[65]$} \\
\hline $\operatorname{Ag}(\mathrm{I})$ & $\begin{array}{l}\text { Two-chamber MFC, } \\
\text { Graphite plates for anode, } \\
\text { Graphite plate for cathode }\end{array}$ & $\begin{array}{l}\text { i. } 0.109 \pm 0017 \mathrm{mM} \\
\text { ii. } 0.025 \pm 0.008 \mathrm{mM}\end{array}$ & $\begin{array}{c}109 \mathrm{~mW} / \mathrm{m}^{2} \\
\text { (For acetate COD } 500 \\
\mathrm{mg} / \mathrm{L})\end{array}$ & [63] \\
\hline $\mathrm{Au}(\mathrm{III})$ & $\begin{array}{l}\text { Two-chamber MFC } \\
\text { Carbon brush for anode, } \\
\text { Carbon cloth for cathode }\end{array}$ & $\begin{array}{c}99.88 \% \\
\text { (for } 200 \mathrm{mg} / \mathrm{L} \mathrm{Au}(\mathrm{III}) \text { ) }\end{array}$ & $\begin{array}{c}6.58 \mathrm{~W} / \mathrm{m}^{2} \\
\text { (For } 2000 \mathrm{ppm} \mathrm{Au}(\mathrm{III}))\end{array}$ & [45] \\
\hline $\mathrm{V}(\mathrm{V})$ & $\begin{array}{l}\text { Two-chamber MFC, } \\
\text { Carbon fiber felt for anode, } \\
\text { Carbon fiber felt for cathode }\end{array}$ & $100 \%$ & $529 \pm 12 \mathrm{~mW} / \mathrm{m}^{2}$ & [66] \\
\hline $\mathrm{Tl}(\mathrm{I})$ & $\begin{array}{c}\text { Single-chamber MFC, } \\
\text { Carbon felt for anode, } \\
\text { Carbon paper/Pt coated for cathode }\end{array}$ & $67.2 \%$ & $457.8 \pm 15.2 \mathrm{~mW} / \mathrm{m}^{2}$ & {$[64]$} \\
\hline $\begin{array}{l}\mathrm{Cr}(\mathrm{VI}) \text { and } \\
\quad \mathrm{Pb}(\mathrm{II})\end{array}$ & $\begin{array}{c}\text { Two double-chamber MFC-MEC, } \\
\text { Carbon felt anode and carbon cloth cathode } \\
\text { for } \mathrm{Cr}(\mathrm{VI})-\mathrm{MFC} \text {; } \\
\text { Carbon felt anode and carbon cloth (CC)/ } \\
\text { stainless steel mesh (SSM)/ nickel foam (NF) } \\
\text { cathode for } \mathrm{Pb}(\mathrm{II})-\mathrm{MEC}\end{array}$ & $\begin{array}{c}\mathrm{Pb}(\mathrm{II}) \text { reduction } \\
\text { efficiency } 100 \% \text {; } \\
\mathrm{Cr}(\mathrm{VI}) \text { reduction rate } \\
1.72 \mathrm{~g} /\left(\mathrm{m}^{3} \cdot \mathrm{h}\right)\end{array}$ & $\begin{array}{c}702.86 \mathrm{~mW} / \mathrm{m}^{2} \\
\text { (For NF cathode) }\end{array}$ & [42] \\
\hline
\end{tabular}

\subsection{Mercury (Hg) Removal}

Wang et al. [41] investigated the effects of the $\mathrm{pH}$ and initial $\mathrm{Hg}^{2+}$ concentration on the performance of a two-chamber MFC for $\mathrm{Hg}^{2+}$ removal and power generation. After a $5 \mathrm{~h}$ reaction, the initial $50 \mathrm{mg} / \mathrm{L}$ $\mathrm{Hg}^{2+}$ was deceased to $3.08 \pm 0.07,4.21 \pm 0.34,4.84 \pm 0.00$, and $5.25 \pm 0.36 \mathrm{mg} / \mathrm{L}$ at $\mathrm{pH} 2,3,4$, and 4.8, respectively. In addition, higher removal rate was realized with higher initial $\mathrm{Hg}^{2+}$ concentration in $4 \mathrm{~h}$. The maximum power generation was obtained at $\mathrm{pH} 2$ with the initial $\mathrm{Hg}^{2+}$ concentration of $100 \mathrm{mg} / \mathrm{L}$, about $433.1 \mathrm{~mW} / \mathrm{m}^{2}$ in comparison to that of lower initial $\mathrm{Hg}^{2+}$ concentration $(25$ and $50 \mathrm{mg} / \mathrm{L}$ ).

\subsection{Silver $(A g)$ Removal}

Tao et al. [63] confirmed that the recovery of silver through the cathodic reduction in MFCs was related to metal forms in the terms of $\mathrm{Ag}(\mathrm{I})$ ions and $\mathrm{Ag}(\mathrm{I})$ thiosulfate complex $\left[\mathrm{AgS}_{2} \mathrm{O}_{3}\right]^{-}$. Firstly, 
the increased $\mathrm{pH}$ (from 2 to 6.6) had less impact on the reduction of $\mathrm{Ag}^{+}$, but higher $\mathrm{pH}$ tended to accelerate the reduction of $\left[\mathrm{AgS}_{2} \mathrm{O}_{3}\right]^{-}$. The reduction rate of $\mathrm{Ag}^{+}$ions was higher than that of $\left[\mathrm{AgS}_{2} \mathrm{O}_{3}\right]^{-}$at $\mathrm{pH}$ 4.0. For $\mathrm{Ag}^{+}$of $110 \mathrm{mg} / \mathrm{L}$ from the simulated photographic wastewater. In addition, the $\mathrm{Ag}^{+}$concentration decreased faster in the electrolysis reactors than in MFCs before reaching $20 \mathrm{mg} / \mathrm{L}$. After that, $\mathrm{Ag}(\mathrm{I})$ declined continuously and the final removal efficiency in MFCs was above $95 \%$ versus $80 \%$ in the electrolysis reactors.

\subsection{Thallium (Tl) Removal}

The redox potential of the pair $\mathrm{Tl}(\mathrm{III}) / \mathrm{Tl}(\mathrm{I})\left(E^{0}=-1.26 \mathrm{~V}\right)$ indicates that the oxidation of $\mathrm{Tl}(\mathrm{I})$ to $\mathrm{Tl}(\mathrm{III})$ is relatively easier to achieve. Unlike other cathodic reduction of heavy metals in MFCs, $\mathrm{Tl}(\mathrm{I})$ was oxidized to $\mathrm{Tl}(\mathrm{III})$ in the anode and then precipitated as $\mathrm{Tl}(\mathrm{OH})_{3}$ which would be easier to be removed from aqueous solution. A single-chamber air-cathode MFC was constructed to support spontaneous $\mathrm{Tl}(\mathrm{I})$ oxidation with electricity generation [64]. Result showed that the $\mathrm{Tl}(\mathrm{I})$ removal efficiency was over $67.2 \% \pm 2.3 \%$ in $72 \mathrm{~h}$ with the initial $\mathrm{Tl}(\mathrm{I})$ concentration of $100 \mu \mathrm{g} / \mathrm{L}$, and the maximum power density of $457.8 \pm 15.2 \mathrm{~mW} / \mathrm{m}^{2}$ was obtained.

On practical aspects, MFCs were applied for the remediation of various heavy metals by bioelectrocatalysis as metal ions can be reduced and deposited by microbes. Almost all silver (Ag) and vanadium (V) was removed using two chamber MFCs, when concentrations were 50 and $200 \mathrm{mg} / \mathrm{L}$, respectively $[65,66]$. Microbial-assisted $\mathrm{Cr}(\mathrm{VI})$ reduction was reported in a two-chamber microbial fuel cell where Trichococcus pasteurii and Pseudomonas aeruginosa played a major role [67]. A very high concentration of vanadium $(\mathrm{V})$ with $300 \mathrm{mg} / \mathrm{L} \mathrm{NaVO} 3$ into the anode chamber with Rhodoferax ferrireducens was treated that resulted in a reduction ratio of $\mathrm{NaVO}_{3}$ of $75.8 \%$ [68].

In one of studies, it was found that $1.6 \mathrm{~g} \mathrm{Ag}$ could be deposited on cathode with over $99.9 \%$ silver ions removed from the catholyte in the treatment of acetate wastewater [69]. About total of 50 and $200 \mathrm{mg} \mathrm{Se} / \mathrm{L}$ selenite was removed in 48 and $72 \mathrm{~h}$, respectively using MFCs [70]. While treating $1000 \mathrm{mg} / \mathrm{L} \mathrm{Cu}$ (II)-containing wastewater, about $98 \%$ of cathodic $\mathrm{Cu}$ (II) was removed in a dual-chamber MFC in $288 \mathrm{~h}$ [71]. The $96 \%$ cathodic reduction of $\mathrm{Cu}$ (II) was $96 \%$ for an initial concentration of $350 \mathrm{mg}$ $\mathrm{Cu}$ per $\mathrm{L}$ in $12 \mathrm{~h}$ [72]. A total of eight heavy metals including $\mathrm{Se}, \mathrm{Ba}, \mathrm{Sr}, \mathrm{Zn}, \mathrm{Mo}, \mathrm{Cu}, \mathrm{Cr}$, and $\mathrm{Pb}$ were removed with as high as $97.8 \%$ of selenium during the treatment of oil sand tailings [73].

Although MFCs were applied to treat most of the heavy metals, the majority of researchers so far focused on Cr removal that could be due to its high redox potential. Still, there exists limitation due to obstacles in the system architecture of MFCs in some cases and process scale-up in heavy metal treatment. The environmental conditions (sun, wind, rain, temperature, etc.), excess biofilm growth on electrodes, and indigenous microbial community could pose additional problems to run MFCs practically, especially on-site or in field studies.

\section{Biological Reduction of Heavy Metals from Soil in MFCs}

The feasibility of MFCs in remediating heavy metal-contaminated soil was investigated in some studies; however, to date, the studies of soil MFCs for heavy metals are relatively few. A summary of some soil MFC applications on heavy metal removal is presented in Table 2. The remediation of heavy metals in soil driven by MFCs is better described as the metal's migration from the anode to the cathode. As a consequence, after remediation, the heavy metal concentration increases in the cathode regions and decreases in the anode regions.

A soil MFC was constructed to produce electricity and remediate $\mathrm{Cu}$-contaminated soil by Wang et al. [74]. Results showed that the $\mathrm{Cu}$ migration process was enhanced by the electrical field, not diffusion or leaching, and the time and space distribution of water soluble and total copper changed obviously with the increased metal concentration gradient from the anode to the cathode. Meanwhile, the soil $\mathrm{pH}$ changed significantly compared to control group and the $\mathrm{pH}$ gap between the cathode and the anode reached 2.25 units. The similar $\mathrm{pH}$ variation and the migration process of $\mathrm{Pb}$ and $\mathrm{Cd}$ in soil 
were also reported in other study [75]. In addition, soil is a more complex medium than water, and soil properties affect the remediation efficiency of metal-contaminated soil using MFCs [76,77].

Table 2. MFCs for the removal of heavy metals from soil.

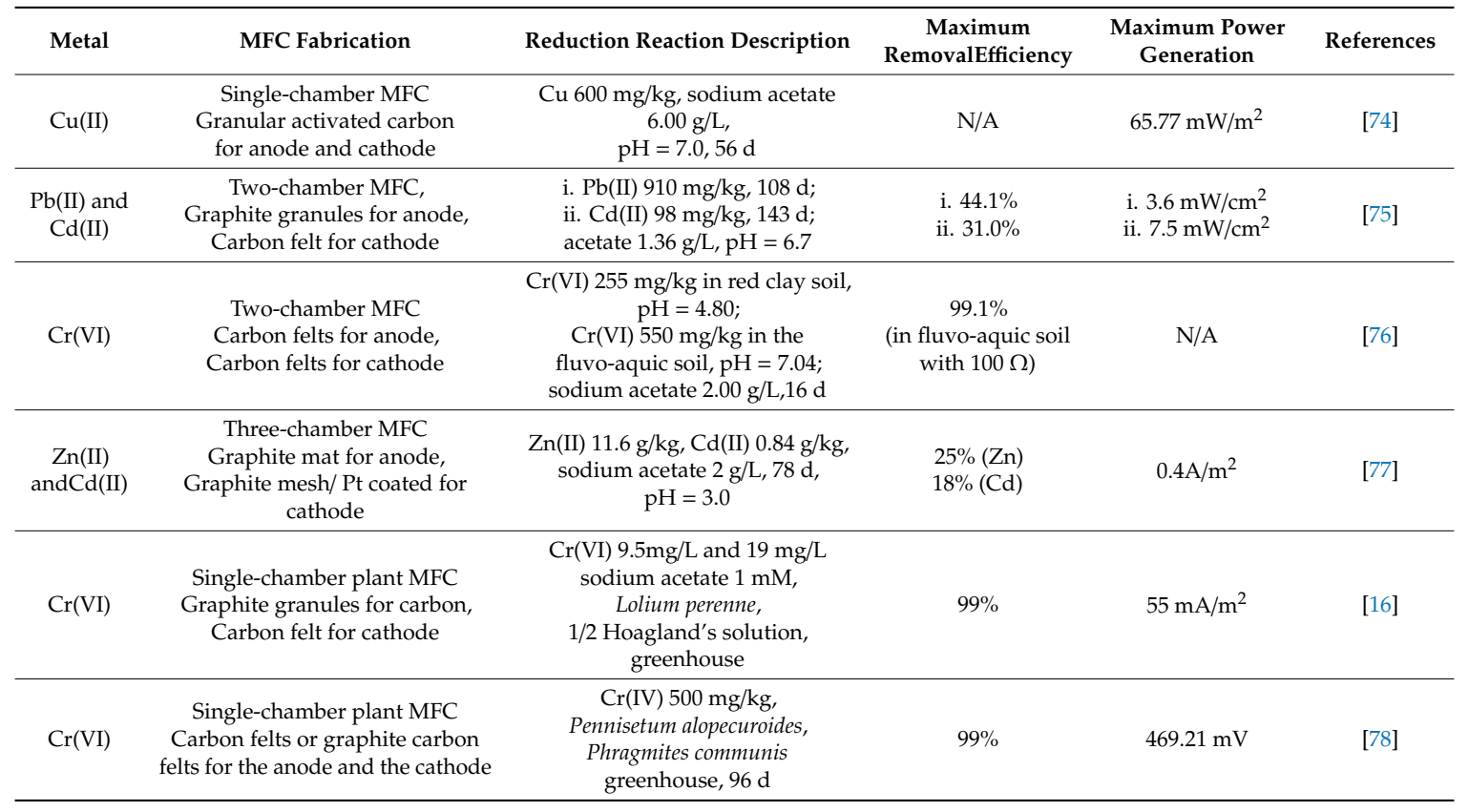

The remediation of two $\mathrm{Cr}(\mathrm{VI})$-contaminated soils: red clay soil and fluvo-aquic soil, using MFCs with two different external resistances were investigated. After remediation for 16 days, the $\mathrm{Cr}(\mathrm{VI})$ removal efficiency in the fluvo-aquic soil was $99.1 \%$ with $100 \Omega$ and $64.3 \%$ with $1000 \Omega$, much higher than those in the red clay soil (62.7\% with $100 \Omega$ and $50.4 \%$ with $1000 \Omega$ ). MFCs can serve as a potential and sustainable approach to remediate heavy metal-contaminated soil, but as shown in Table 2, the metals removal efficiencies in soil by a single MFC are not high. Thus, the combination of soil MFCs and other methods were developed to improve heavy metal removal efficiency, such as plant-microbial fuel cell (PMFC) [16,78].

The coupling of plants to soil MFC is a clever pathway that can convert solar energy into bioelectricity based on a unique plant-microbe relationship, and it is a promising modification of MFC to remediate the metal-contaminated soil in situ [79]. PMFC can utilize root exudates and other organics as substrates to generate electrons with the help of electrochemically active microorganisms in the rhizosphere of a plant. PMFC was applied for the removal of $\mathrm{Cr}(\mathrm{VI})$ successfully and the $\mathrm{Cr}(\mathrm{VI})$ removal efficiency of $99 \%$ was realized [16]. Meanwhile, the maximum current density of the PMFC reached $55 \mathrm{~mA} / \mathrm{m}^{2}$ at an initial $\mathrm{Cr}(\mathrm{VI})$ concentration of $19 \mathrm{mg} / \mathrm{L}$, which was approximately two-times higher than that at an initial $\mathrm{Cr}(\mathrm{VI})$ concentration of $9 \mathrm{mg} / \mathrm{L}$. The high $\mathrm{Cr}(\mathrm{VI})$ removal efficiency was attributed to plant uptake, bioelectrochemical reduction, direct reduction by $\mathrm{Cr}$-reducing microorganisms, and adsorption by electrodes in PMFC. A large proportion of the total $\mathrm{Cr}(\mathrm{VI}) \mathrm{was}$ removed by bioelectrochemical reduction and plant uptake with an approximate share of $57.1 \%$ and $29.4 \%$, respectively. In another study, Pennisetum alopecuroides and Phragmites communis were selected as wetland plants for the PMFC experiment of the $\mathrm{Cr}(\mathrm{VI})$ removal in soil. Result showed that the $\mathrm{Cr}(\mathrm{VI})$ removal efficiency reached $99 \%$ in all PMFCs systems. The daily average voltage value of PMFC systems of P. alopecuroides in closed circuit using the graphite carbon felt electrodes could reach $469.21 \mathrm{mV}$. In sum, MFCs and their modification to PMFCs are promising techniques for heavy metal-contaminated soil remediation. Moreover, the performances of PMFCs were enhanced significantly compared to that of the traditional MFCs in soil, especially for the high metals removal. 


\section{Conclusions}

In conclusion, MFC is a promising technology for simultaneous pollutant reduction and electricity generation. The cathodic reduction coupled to organic substrate oxidation has successfully removed several heavy metals from wastewater and soil. In addition to combining biological technology with electrochemical technology, the unique advantages of MFCs are due to simple operation and easy construction resulting not only in heavy metal removal but also in metal recovery for reuse and recycling. However, the current MFCs are not capable of competing with and replacing the conventional energy generation approach based on fossil fuels and there are still many challenges for their future application. For this, research toward improving power generation, reducing the cost, and long-term operation of MFCs need to be intensely explored.

Author Contributions: V.A. guided the structure and content of the article. C.F. wrote the article, while V.A. further revised and edited the contents.

Funding: This work was supported by the National Natural Science Foundation of China (grant no: 41950410576).

Conflicts of Interest: The authors declare no conflict of interest.

\section{References}

1. Baicha, Z.; Salar-García, M.J.; Ortiz-Martínez, V.M.; Hernández-Fernández, F.J.; de los Ríos, A.P.; Labjar, N.; Lotfi, E.; Elmahi, M. A critical review on microalgae as an alternative source for bioenergy production: A promising low cost substrate for microbial fuel cells. Fuel Process. Technol. 2016, 154, 104-116. [CrossRef]

2. Potter, M.C.; Waller, A.D. Electrical effects accompanying the decomposition of organic compounds. Proc. R. Soc. Lond. Ser. B Contain. Pap. Biol. Character 1911, 84, 260-276. [CrossRef]

3. Slate, A.J.; Whitehead, K.A.; Brownson, D.A.C.; Banks, C.E. Microbial fuel cells: An overview of current technology. Renew. Sustain. Energy Rev. 2019, 101, 60-81. [CrossRef]

4. Wang, H.; Park, J.-D.; Ren, Z.J. Practical Energy Harvesting for Microbial Fuel Cells: A Review. Environ. Sci. Technol. 2015, 49, 3267-3277. [CrossRef] [PubMed]

5. Palanisamy, G.; Jung, H.-Y.; Sadhasivam, T.; Kurkuri, M.D.; Kim, S.C.; Roh, S.-H. A comprehensive review on microbial fuel cell technologies: Processes, utilization, and advanced developments in electrodes and membranes. J. Clean. Prod. 2019, 221, 598-621. [CrossRef]

6. Du, Z.; Li, H.; Gu, T. A state of the art review on microbial fuel cells: A promising technology for wastewater treatment and bioenergy. Biotechnol. Adv. 2007, 25, 464-482. [CrossRef] [PubMed]

7. Pant, D.; Van Bogaert, G.; Diels, L.; Vanbroekhoven, K. A review of the substrates used in microbial fuel cells (MFCs) for sustainable energy production. Bioresour. Technol. 2010, 101, 1533-1543. [CrossRef]

8. Liu, J.; Qiao, Y.; Lu, Z.S.; Song, H.; Li, C.M. Enhance electron transfer and performance of microbial fuel cells by perforating the cell membrane. Electrochem. Commun. 2012, 15, 50-53. [CrossRef]

9. Rabaey, K.; Boon, N.; Höfte, M.; Verstraete, W. Microbial Phenazine Production Enhances Electron Transfer in Biofuel Cells. Environ. Sci. Technol. 2005, 39, 3401-3408. [CrossRef]

10. Logan, B.; Cheng, S.; Watson, V.; Estadt, G. Graphite Fiber Brush Anodes for Increased Power Production in Air-Cathode Microbial Fuel Cells. Environ. Sci. Technol. 2007, 41, 3341-3346. [CrossRef]

11. Wei, J.; Liang, P.; Huang, X. Recent progress in electrodes for microbial fuel cells. Bioresour. Technol. 2011, 102, 9335-9344. [CrossRef] [PubMed]

12. He, Z.; Minteer, S.D.; Angenent, L.T. Electricity Generation from Artificial Wastewater Using an Upflow Microbial Fuel Cell. Environ. Sci. Technol. 2005, 39, 5262-5267. [CrossRef] [PubMed]

13. Aelterman, P.; Rabaey, K.; Pham, H.T.; Boon, N.; Verstraete, W. Continuous Electricity Generation at High Voltages and Currents Using Stacked Microbial Fuel Cells. Environ. Sci. Technol. 2006, 40, 3388-3394. [CrossRef] [PubMed]

14. Liu, H.; Ramnarayanan, R.; Logan, B.E. Production of Electricity during Wastewater Treatment Using a Single Chamber Microbial Fuel Cell. Environ. Sci. Technol. 2004, 38, 2281-2285. [CrossRef] [PubMed]

15. Min, B.; Kim, J.; Oh, S.; Regan, J.M.; Logan, B.E. Electricity generation from swine wastewater using microbial fuel cells. Water Res. 2005, 39, 4961-4968. [CrossRef] [PubMed] 
16. Habibul, N.; Hu, Y.; Wang, Y.-K.; Chen, W.; Yu, H.-Q.; Sheng, G.-P. Bioelectrochemical Chromium(VI) Removal in Plant-Microbial Fuel Cells. Environ. Sci. Technol. 2016, 50, 3882-3889. [CrossRef]

17. Min, B.; Logan, B.E. Continuous Electricity Generation from Domestic Wastewater and Organic Substrates in a Flat Plate Microbial Fuel Cell. Environ. Sci. Technol. 2004, 38, 5809-5814. [CrossRef]

18. Logan, B.E.; Rabaey, K. Conversion of Wastes into Bioelectricity and Chemicals by Using Microbial Electrochemical Technologies. Science 2012, 337, 686. [CrossRef]

19. Rozendal, R.A.; Hamelers, H.V.M.; Rabaey, K.; Keller, J.; Buisman, C.J.N. Towards practical implementation of bioelectrochemical wastewater treatment. Trends Biotechnol. 2008, 26, 450-459. [CrossRef]

20. Rossi, R.; Wang, X.; Yang, W.; Logan, B.E. Impact of cleaning procedures on restoring cathode performance for microbial fuel cells treating domestic wastewater. Bioresour. Technol. 2019, 290, 121759. [CrossRef]

21. He, L.; Du, P.; Chen, Y.; Lu, H.; Cheng, X.; Chang, B.; Wang, Z. Advances in microbial fuel cells for wastewater treatment. Renew. Sustain. Energy Rev. 2017, 71, 388-403. [CrossRef]

22. Mohsen, M.; Wang, Q.; Zhang, L.; Sun, L.; Lin, C.; Yang, H. Heavy metals in sediment, microplastic and sea cucumber Apostichopus japonicus from farms in China. Mar. Pollut. Bull. 2019, 143, 42-49. [CrossRef] [PubMed]

23. Abou-Elwafa, S.F.; Amin, A.E.-E.A.Z.; Shehzad, T. Genetic mapping and transcriptional profiling of phytoremediation and heavy metals responsive genes in sorghum. Ecotoxicol. Environ. Saf. 2019, 173, 366-372. [CrossRef] [PubMed]

24. Wang, L.; Wang, Y.; Ma, F.; Tankpa, V.; Bai, S.; Guo, X.; Wang, X. Mechanisms and reutilization of modified biochar used for removal of heavy metals from wastewater: A review. Sci. Total Environ. 2019, 668, 1298-1309. [CrossRef]

25. Barakat, M.A. New trends in removing heavy metals from industrial wastewater. Arab. J. Chem. 2011, 4, 361-377. [CrossRef]

26. Zwain, H.M.; Vakili, M.; Dahlan, I. Waste material adsorbents for zinc removal from wastewater: A comprehensive review. Int. J. Chem. Eng. 2014, 2014, 347912. [CrossRef]

27. WHO. Guidelines for Drinking-Water Quality: Fourth Edition Incorporating the First Addendum; World Health Organization: Geneva, Switerland, 2017.

28. Nasir, A.M.; Goh, P.S.; Abdullah, M.S.; Cheer, N.B.; Ismail, A.F. Adsorptive Nanocomposite Membranes for Heavy Metal Remediation: Recent Progresses and Challenges. Chemosphere 2019, 232, 96-112. [CrossRef]

29. National Bureau of Statistics of China (NBSC). Available online: http://data.stats.gov.cn (accessed on 15 September 2019).

30. Wei, B.; Yang, L. A review of heavy metal contaminations in urban soils, urban road dusts and agricultural soils from China. Microchem. J. 2010, 94, 99-107. [CrossRef]

31. Kelepertzis, E. Accumulation of heavy metals in agricultural soils of Mediterranean: Insights from Argolida basin, Peloponnese, Greece. Geoderma 2014, 221-222, 82-90. [CrossRef]

32. Maas, S.; Scheifler, R.; Benslama, M.; Crini, N.; Lucot, E.; Brahmia, Z.; Benyacoub, S.; Giraudoux, P. Spatial distribution of heavy metal concentrations in urban, suburban and agricultural soils in a Mediterranean city of Algeria. Environ. Pollut. 2010, 158, 2294-2301. [CrossRef]

33. He, Z.; Huang, Y.; Manohar, A.K.; Mansfeld, F. Effect of electrolyte $\mathrm{pH}$ on the rate of the anodic and cathodic reactions in an air-cathode microbial fuel cell. Bioelectrochemistry 2008, 74, 78-82. [CrossRef] [PubMed]

34. Nancharaiah, Y.V.; Venkata Mohan, S.; Lens, P.N.L. Metals removal and recovery in bioelectrochemical systems: A review. Bioresour. Technol. 2015, 195, 102-114. [CrossRef] [PubMed]

35. Wang, H.; Ren, Z.J. Bioelectrochemical metal recovery from wastewater: A review. Water Res. 2014, 66, 219-232. [CrossRef] [PubMed]

36. Wang, G.; Huang, L.; Zhang, Y. Cathodic reduction of hexavalent chromium [Cr(VI)] coupled with electricity generation in microbial fuel cells. Biotechnol. Lett. 2008, 30, 1959. [CrossRef] [PubMed]

37. Liu, H.; Cheng, S.; Logan, B.E. Power Generation in Fed-Batch Microbial Fuel Cells as a Function of Ionic Strength, Temperature, and Reactor Configuration. Environ. Sci. Technol. 2005, 39, 5488-5493. [CrossRef] [PubMed]

38. Li, Z.; Zhang, X.; Lei, L. Electricity production during the treatment of real electroplating wastewater containing Cr6+ using microbial fuel cell. Process Biochem. 2008, 43, 1352-1358. [CrossRef] 
39. Heijne, A.T.; Liu, F.; Weijden, R.v.d.; Weijma, J.; Buisman, C.J.N.; Hamelers, H.V.M. Copper Recovery Combined with Electricity Production in a Microbial Fuel Cell. Environ. Sci. Technol. 2010, 44, 4376-4381. [CrossRef]

40. Tao, H.-C.; Liang, M.; Li, W.; Zhang, L.-J.; Ni, J.-R.; Wu, W.-M. Removal of copper from aqueous solution by electrodeposition in cathode chamber of microbial fuel cell. J. Hazard. Mater. 2011, 189, 186-192. [CrossRef]

41. Wang, Z.; Lim, B.; Choi, C. Removal of $\mathrm{Hg} 2+$ as an electron acceptor coupled with power generation using a microbial fuel cell. Bioresour. Technol. 2011, 102, 6304-6307. [CrossRef]

42. Li, M.; Zhou, S.; Xu, Y. Performance of $\mathrm{Pb}(\mathrm{II})$ reduction on different cathodes of microbial electrolysis cell driven by $\mathrm{Cr}(\mathrm{VI})$-reduced microbial fuel cell. J. Power Sources 2019, 418, 1-10. [CrossRef]

43. Wang, Q.; Huang, L.; Pan, Y.; Zhou, P.; Quan, X.; Logan, B.E.; Chen, H. Cooperative cathode electrode and in situ deposited copper for subsequent enhanced $\mathrm{Cd}(\mathrm{II})$ removal and hydrogen evolution in bioelectrochemical systems. Bioresour. Technol. 2016, 200, 565-571. [CrossRef] [PubMed]

44. Rismani-Yazdi, H.; Carver, S.M.; Christy, A.D.; Tuovinen, O.H. Cathodic limitations in microbial fuel cells: An overview. J. Power Sources 2008, 180, 683-694. [CrossRef]

45. Choi, C.; Hu, N. The modeling of gold recovery from tetrachloroaurate wastewater using a microbial fuel cell. Bioresour. Technol. 2013, 133, 589-598. [CrossRef] [PubMed]

46. Ha, P.T.; Moon, H.; Kim, B.H.; Ng, H.Y.; Chang, I.S. Determination of charge transfer resistance and capacitance of microbial fuel cell through a transient response analysis of cell voltage. Biosens. Bioelectron. 2010, 25, 1629-1634. [CrossRef] [PubMed]

47. Zhang, F.; Chen, G.; Hickner, M.A.; Logan, B.E. Novel anti-flooding poly(dimethylsiloxane) (PDMS) catalyst binder for microbial fuel cell cathodes. J. Power Sources 2012, 218, 100-105. [CrossRef]

48. Noori, M.T.; Mukherjee, C.K.; Ghangrekar, M.M. Enhancing performance of microbial fuel cell by using graphene supported V2O5-nanorod catalytic cathode. Electrochim. Acta 2017, 228, 513-521. [CrossRef]

49. Zhou, M.; Chi, M.; Luo, J.; He, H.; Jin, T. An overview of electrode materials in microbial fuel cells. J. Power Sources 2011, 196, 4427-4435. [CrossRef]

50. Li, M.; Zhou, S.; Xu, Y.; Liu, Z.; Ma, F.; Zhi, L.; Zhou, X. Simultaneous Cr(VI) reduction and bioelectricity generation in a dual chamber microbial fuel cell. Chem. Eng. J. 2018, 334, 1621-1629. [CrossRef]

51. Zhu, Y.; Fan, W.; Zhou, T.; Li, X. Removal of chelated heavy metals from aqueous solution: A review of current methods and mechanisms. Sci. Total Environ. 2019, 678, 253-266. [CrossRef]

52. Li, W.-W.; Yu, H.-Q.; He, Z. Towards sustainable wastewater treatment by using microbial fuel cells-centered technologies. Energy Environ. Sci. 2014, 7, 911. [CrossRef]

53. Veglio, F.; Beolchini, F. Removal of metals by biosorption: A review. Hydrometallurgy 1997, 44, $301-316$. [CrossRef]

54. Ezziat, L.; Elabed, A.; Ibnsouda, S.; El Abed, S. Challenges of microbial fuel cell architecture on heavy metal recovery and removal from wastewater. Front. Energy Res. 2019, 7, 1. [CrossRef]

55. Abourached, C.; Catal, T.; Liu, H. Efficacy of single-chamber microbial fuel cells for removal of cadmium and zinc with simultaneous electricity production. Water Res. 2014, 51, 228-233. [CrossRef] [PubMed]

56. Zhang, Y.; He, Q.; Xia, L.; Li, Y.; Song, S. Algae cathode microbial fuel cells for cadmium removal with simultaneous electricity production using nickel foam/graphene electrode. Biochem. Eng. J. 2018, 138, 179-187. [CrossRef]

57. Miran, W.; Jang, J.; Nawaz, M.; Shahzad, A.; Sang, E.J.; Che, O.J.; Lee, D.S. Mixed sulfate-reducing bacteria-enriched microbial fuel cells for the treatment of wastewater containing copper. Chemosphere 2017, 189, 134. [CrossRef]

58. Wu, Y.; Zhao, X.; Jin, M.; Li, Y.; Li, S.; Kong, F.; Nan, J.; Wang, A. Copper removal and microbial community analysis in single-chamber microbial fuel cell. Bioresour. Technol. 2018, 253, 372-377. [CrossRef] [PubMed]

59. Li, W.-W.; Sheng, G.-P.; Liu, X.-W.; Yu, H.-Q. Recent advances in the separators for microbial fuel cells. Bioresour. Technol. 2011, 102, 244-252. [CrossRef]

60. Zhang, B.; Feng, C.; Ni, J.; Zhang, J.; Huang, W. Simultaneous reduction of vanadium (V) and chromium (VI) with enhanced energy recovery based on microbial fuel cell technology. J. Power Sources 2012, 204, 34-39. [CrossRef]

61. Colantonio, N.; Kim, Y. Cadmium (II) removal mechanisms in microbial electrolysis cells. J. Hazard. Mater. 2016, 311, 134-141. [CrossRef] 
62. Choi, C.; Hu, N.; Lim, B. Cadmium recovery by coupling double microbial fuel cells. Bioresour. Technol. 2014, 170, 361-369. [CrossRef]

63. Tao, H.-C.; Gao, Z.-Y.; Ding, H.; Xu, N.; Wu, W.-M. Recovery of silver from silver(I)-containing solutions in bioelectrochemical reactors. Bioresour. Technol. 2012, 111, 92-97. [CrossRef] [PubMed]

64. Wang, Z.; Zhang, B.; Jiang, Y.; Li, Y.; He, C. Spontaneous thallium (I) oxidation with electricity generation in single-chamber microbial fuel cells. Appl. Energ. 2018, 209, 33-42. [CrossRef]

65. Choi, C.; Cui, Y. Recovery of silver from wastewater coupled with power generation using a microbial fuel cell. Bioresour. Technol. 2012, 107, 522-525. [CrossRef] [PubMed]

66. Qiu, R.; Zhang, B.; Li, J.; Lv, Q.; Wang, S.; Gu, Q. Enhanced vanadium (V) reduction and bioelectricity generation in microbial fuel cells with biocathode. J. Power Sources 2017, 359, 379-383. [CrossRef]

67. Tandukar, M.; Ulas, T.; Pavlostathis, S.G. Biological chromium (VI) reduction in microbial fuel cell: A three in one approach. Proc. Water Environ. Fed. Sess. 2009, 11-20, 527-535. [CrossRef]

68. Li, Y.; Lu, A.; Ding, H.; Jin, S.; Yan, Y.; Wanga, C.; Zen, C.; Wang, X. Cr(VI) reduction at rutile-catalyzed cathode in microbial fuel cells. Electrochem. Commun. 2009, 11, 1496-1499. [CrossRef]

69. Zhang, L.J.; Tao, H.C.; Wei, X.Y.; Lei, T.; Li, J.B.; Wang, A.J.; Wu, W.M. Bioelectrochemical recovery of ammonia-copper(II) complexes from wastewater using a dual chamber microbial fuel cell. Chemosphere 2012, 89, 1177-1182. [CrossRef]

70. Jiang, Y.; Ulrich, A.C.; Liu, Y. Coupling bioelectricity generation and oil sands tailings treatment using microbial fuel cells. Bioresour. Technol. 2013, 139, 349-354. [CrossRef]

71. Catal, T.; Hakan Bermek, H.; Liu, H. Removal of selenite from wastewater using microbial fuel cells. Biotechnol. Lett. 2009, 31, 1211-1216. [CrossRef]

72. Wang, Y.H.; Wang, B.S.; Pan, B.; Chen, Q.Y.; Yan, W. Electricity production from a bio-electrochemical cell for silver recovery in alkaline media. Appl. Energy 2013, 112, 1337-1341. [CrossRef]

73. Liang, M.; Tao, H.C.; Li, S.F.; Li, W.; Zhang, L.I.; Ni, J.R. Treatment of Cu2+-containing wastewater by microbial fuel cell with excess sludge as anodic substrate. Environ. Sci. Technol. 2011, 32, 179-185.

74. Wang, H.; Song, H.; Yu, R.; Cao, X.; Fang, Z.; Li, X. New process for copper migration by bioelectricity generation in soil microbial fuel cells. Environ. Sci. Pollut. Res. 2016, 23, 13147-13154. [CrossRef] [PubMed]

75. Habibul, N.; Hu, Y.; Sheng, G.-P. Microbial fuel cell driving electrokinetic remediation of toxic metal contaminated soils. J. Hazard. Mater. 2016, 318, 9-14. [CrossRef] [PubMed]

76. Wang, C.; Deng, H.; Zhao, F. The Remediation of Chromium (VI)-Contaminated Soils Using Microbial Fuel Cells. Soil Sediment Contam. Int. J. 2016, 25, 1-12. [CrossRef]

77. Chen, Z.; Zhu, B.-K.; Jia, W.-F.; Liang, J.-H.; Sun, G.-X. Can electrokinetic removal of metals from contaminated paddy soils be powered by microbial fuel cells? Environ. Technol. Innov. 2015, 3, 63-67. [CrossRef]

78. Guan, C.-Y.; Tseng, Y.-H.; Tsang, D.C.W.; Hu, A.; Yu, C.-P. Wetland plant microbial fuel cells for remediation of hexavalent chromium contaminated soils and electricity production. J. Hazard. Mater. 2019, 365, 137-145. [CrossRef]

79. Nitisoravut, R.; Regmi, R. Plant microbial fuel cells: A promising biosystems engineering. Renew. Sustain. Energy Rev. 2017, 76, 81-89. [CrossRef]

(C) 2019 by the authors. Licensee MDPI, Basel, Switzerland. This article is an open access article distributed under the terms and conditions of the Creative Commons Attribution (CC BY) license (http://creativecommons.org/licenses/by/4.0/). 